\title{
Community Participation in Sustainable Valorisation of Cultural Heritage: The Case of the Municipality of Vrsar
}

\author{
Kristina Afrić Rakitovac \\ Juraj Dobrila University of Pula, \\ Croatia \\ kafric@unipu.hr \\ Nataša Urošević \\ Juraj Dobrila University of Pula, \\ Croatia \\ natasa.urosevic@unipu.hr
}

\author{
Nikola Vojnović \\ Juraj Dobrila University of Pula, \\ Croatia \\ nvojnov@unipu.hr
}

Sustainable tourism, as tourism that respects both residents and visitors, cultural heritage and the environment, can offer appropriate models for sustainable cultural heritage management and local economy development. Community participation is one of the fundamental principles of sustainable tourism. It was introduced in tourism studies more than three decades ago and elaborated through different methodological approaches and research. The purpose of this paper is to elaborate the local community perspectives regarding sustainable valorisation of cultural and archaeological heritage. The research was realised within the framework of ArchaeoCulTour, a recent scientific project whose main goal is to analyse the development potential of archaeological heritage through sustainable tourism in Istria County, Croatia. The research has considered the Municipality of Vrsar in Western Istria, a typical Mediterranean tourist destination, characterised by mass tourism and high seasonality, as a case study. The research has shown that the residents in the Municipality of Vrsar partially support the current tourism development model, faced with different sustainability challenges and many infrastructural problems. Residents are interested in being better informed and more involved in the tourism planning process and the participatory heritage management models. They agree that the main sustainability issues could be improved through sustainable valorisation of local cultural and natural resources by creating innovative tourism experiences, and they are interested to participate in this co-creating process.

Keywords: tourism destinations, cultural heritage, sustainable cultural tourism, community participation

(cc) BY-SA https://doi.org/10.26493/2335-4194.14.7-22

\section{Introduction}

Tourism destinations, as places with complex economic, urban and residential functions, are not passive locations for tourism activities, but dynamic systems and products of interactions between places and peo- ple, whose transformations depend on a combination of economic, social, political, cultural, historical and ecological factors. Therefore, tourism development planning and destination dynamics should consider all sustainability dimensions and involve all key stake- 
holders. The analysis of dynamic relationships that influence tourism development should explore tourism destinations as relational, intersectoral, collaborative, networked, hybrid, transnational and multiscalar systems.

The main goal of proper destination governance should be sustainable local development, the quality of life for the local community and a high-quality experience for tourists through networking and coordinating all key stakeholders. In order for a destination to be developed successfully, key stakeholders (public and private sectors, local community and tourists) should communicate, learn together, coordinate their development visions and share responsibility. The most challenging part of integrating all key stakeholders in destination governance is their active involvement in the planning process and implementation (Čorak, 2011). In this paper, the authors elaborate destination dynamics in heritage tourism through the participatory management model as one of the key principles of sustainable tourism. The concept is based on the four mutually interdependent pillars of sustainability: the social, economic, environmental and cultural pillars. Sustainable tourism should involve all relevant stakeholders in a tourism destination to recognise and valorise its specific, distinctive characteristics.

The dynamics between tourism destinations, natural and cultural resources and local stakeholders is the most important issue in sustainable tourism development. Since sustainable tourism is focused to benefit local residents, respect local culture, valorise local resources and educate tourists, as well as local residents, all activities and practices of sustainable tourism are directly connected to the four pillars of sustainable development. According to the UN World Tourism Organization (2016), tourism can be a powerful tool for community development and for reducing inequalities if it engages local populations and all key stakeholders in its development, in the framework of the 17 Sustainable Development Goals (SDG) of the 2030 Agenda for Sustainable Development. The local community should benefit from tourism and be actively involved in the tourism planning and heritage management process. Effective participation of local communities in heritage management, both in consultation and decision-making, is the main topic of some key strategic recommendations and conventions, such as the Faro Convention and the European Cultural Heritage Strategy for the 21st century, which work together as guides to social involvement, community collaboration and awareness-raising to ensure 'heritage for all' (Picard, 2017, p. 83).

Destination communities have also come together to resist, negotiate and/or co-create knowledge of their heritage tourism worlds. Heritage tourism knowledge production and distribution have increasingly been considered as collaborative, networked, political, transnational and multiscalar processes (Hollinshead, 1999; Ong et al., 2014; Winter, 2015).

The purpose of this paper is to present changing dynamics in a typical Mediterranean destination, with an emphasis on the role and attitudes of the local community in the collaborative processes of co-creating knowledge of the local cultural heritage. The research presented in this paper was conducted in the framework of the current scientific project 'The Archaeological Landscape in Sustainable Development of Cultural Tourism in Vrsar Municipality - ArchaeoCulTour.' The project is based on the collection, analysis and systematization of data on archaeological sites, and their use in strategic development of cultural tourism in the Municipality of Vrsar. Its objectives include the identification and analysis of archaeological heritage on the basis of field research, analysis of cartography, and aerial photographs; the preservation of archaeological heritage and landscape by continuous monitoring; the valorisation of archaeological heritage in the sustainable development context; an opinion survey among local residents, professionals and tourists on cultural, and in particular archaeological, heritage; the dissemination of the results for raising awareness of cultural tourism by creating new ways of presenting heritage; and the preparation of selected sites for presentation. The main aim of the project is to develop a successful strategy for sustainable growth of cultural tourism in Istria as the most developed Croatian tourist region, characterised by an abundance of archaeological sites, which are unfortunately still not adequately presented, interpreted and valorised.

The authors analysed the situation and the poten- 
tials for the sustainable valorisation of cultural and archaeological heritage in the Municipality of Vrsar in Western Istria, a typical Mediterranean tourist destination characterised by high seasonality, mass tourism concentrated on the coast, and inadequately valorised cultural heritage which is still not recognised as an important and valuable tourism resource. The authors combined qualitative and quantitative methodology which have involved all interested stakeholders (experts, the local community and visitors). The research was organised in three phases. The first phase, conducted in March 2018, included interviews and focus groups with 15 experts, with the aim of defining key issues and collecting information for situational analysis. The local community survey was conducted from March to May 2018, involving 200 inhabitants of Vrsar (with 182 properly completed questionnaires). The third phase of the research, conducted from May to September 2018, involved 820 tourists. In this paper, the authors present the results of the second phase related to attitudes and expectations of the local community regarding valorisation of local cultural heritage through sustainable cultural tourism.

In the next section, the authors elaborate the theoretical framework and literature review concerning the importance of community participation in sustainable valorisation of local cultural heritage. This is followed by a presentation of the results of empirical research related to the attitudes and expectations of the residents of the Municipality of Vrsar regarding the potentials of sustainable valorisation of local cultural heritage. The results are discussed in the concluding part of the paper.

\section{Conceptual Framework and Literature Review}

Sustainable tourism, as tourism that respects both local residents and visitors, the cultural heritage and the environment, can offer appropriate models for sustainable management of cultural heritage and local economy development at the same time. As Goodwin (2011) argues, there is not a unique blueprint for sustainable tourism. The challenges, priorities and solutions vary from place to place, depending on the level of economic development, social conditions, local culture and cultural heritage, environmental factors, nat- ural heritage, etc. From a destination perspective, the planning and implementation of sustainable tourism should involve and respect the long-term interests of all relevant stakeholders.

As Richards and Hall (2003) noted, sustaining local communities has become an essential element of sustainable tourism. If the resources of the host community are not managed in a responsible way, tourism development cannot be expected to be sustainable. On the other hand, sustainability of heritage resources cannot be achieved without the direct involvement of the local community: if heritage is respected, used and managed by the locals, it has better chances to be properly valorised. The rationale of sustainable tourism usually rests on providing long-term economic, social and cultural benefits to the community and its environment. A holistic approach to sustainability requires the continuing/improved social, cultural and economic well-being of human communities to be an integral component of environmental renewal. The balance between tourism development, sustainable valorisation of unique and valuable local resources and community well-being becomes a challenge in the modern world.

The concept of community participation was introduced to tourism studies more than three decades ago (Murphy, 1985 in Šegota et al., 2017). Informed stakeholders' participation and cooperation are some of the most important requirements for the implementation of sustainable tourism development (Mihalic, 2014). The advocates of participatory governance suggest that community participation can increase reliance and public consensus, lead to tourism strategies that correspond to local needs and contribute to destination sustainability (Byrd, Bosley and Dronberer, 2009; Currie, Seaton and Wesley, 2009). According to Gunn (1994) and supported by several studies (Ioannides, 1995; Robson \& Robson, 1996 in Šegota et al., 2017), sustainable tourism development cannot be successful without the support of citizens.

In this paper, the authors assumed that sustainable tourism, as tourism that respects both local residents and their visitors, the cultural heritage and the environment, could offer appropriate models for the sustainable management of cultural heritage and commu- 
nity development at the same time. It is supposed that cultural tourism, which 'cares for the culture it consumes while culturing the consumer' (Richards, 2007, p. 1), as a sustainable alternative to mass tourism, could strengthen the identity and economy of the local community, create new jobs, and increase the quality of life of local residents and a visitor's enjoyment, preserving the natural environment at the same time (Afrić Rakitovac \& Urošević, 2017).

Community participation in the development of sustainable cultural tourism is the main topic of many studies in the tourism field, which focus on the dynamics between tourism development, (un)sustainable use of key resources and local communities' reactions to its consequences (Zolfani et al., 2015). Terzić et al. (2014) have presented a methodology of cultural tourism sustainability indicators (including 30 indicators related to sustainability of heritage resource conservation, sustainability of tourism and tourismrelated sustainability of local community), elaborating studies (Xiang and Wall, 2005) which examined residents' attitudes towards tourism and the impacts tourism can have on a community (Perdue, Long and Allen, 1990; Ap, 1992; Lankford, 1994; Andereck \& Vogt, 2000; Gursoy, Jurowski and Uysal, 2002; McGehee \& Andereck, 2004; Andereck et al., 2005; Dyer et al., 2007; Wang \& Pfister, 2008; Anderleck \& Nyaupane, 2011). According to these authors, opinions and attitudes of local residents on the key values of cultural heritage and their tourist valorisation are important since they create a local perspective for evaluating possibilities to involve geographically limited territories into wider social, cultural and tourism flows.

Models of sustainable tourism development consider not only the aspects of the natural (physical) environment and economic impacts, but the sociocultural dimensions of destinations as well. The most important sociocultural effects of sustainable tourism are the mutual influences and impacts between local residents (community) and the broadest spectrum of tourism activities of a destination. There are numerous positive impacts in that relationship, such as increased local participation in destination activities and events, the strengthening of community values and the revival of traditions, greater security presence, the creation of new community space, exposure to new ideas through globalisation and transnationalism, etc. On the other hand, there are negative impacts such as changes in community structure, loss of authenticity, exceeding social carrying capacity, increases in criminal activity, etc. (Wall \& Mathieson, 2005; Hall \& Page, 2006; Hall, 2007). Despite the positive sociocultural effects of tourism development, the role of the local community in the sustainable tourism of destinations is neglected (Klarin, 2018). Furthermore, the satisfaction of local inhabitants with tourism development is associated with their involvement in tourism planning (Nunkoo \& Ramkissoon, 2010; Choi \& Murray, 2010).

Although scholars suggest and use various terms and phrases in order to explain participatory development strategies, in this research we used the concept of community participation in the tourism development process (СРTDP) which is defined as an adaptive and categorical (flexible) paradigm that allows local communities in various tourist destinations at different levels of development to participate in the decision-making process of tourism development, including sharing the benefits of tourism development, and determining the type and scale of tourism development in their localities (Tosun, 2000; 2005).

According to the analysed literature (Richards \& Munsters, 2010), the most appropriate methodological tools of scientific research of the CP TDP are questionnaires, participatory observation, focus groups and interviews. Recognising the geographical, developmental and economic specificities of the destination of Vrsar during the situational analysis at the beginning of the research, and the results of previous researches, the authors decided to use survey (questionnaire) methods to measure specific local destination dynamics. In scientific and professional publications in Croatia and abroad, there are numerous researches on local residents-tourism relationships and connections. The most important are those in which surveys, participatory observation, focus groups and interviews were used in order to consider the interconnections between local populations, including participatory models and the broadest aspects of tourism activities, especially in regions similar to the $\mathrm{Mu}$ nicipality of Vrsar. Such researches consider the so- 
cioeconomic and sociocultural impacts and transformations of tourism regions: Cape Cod (USA), Costa Blanca (Spain), Crete (Greece), Arizona (u s A), Victoria (Australia), the Slovenian Coast (Slovenia), Inland Istria, and the cities of Pula, Bjelovar and Čakovec (Croatia).

Among the earliest research on the interconnection of the local population and tourism activities and development was a study conducted in an attempt to empirically examine the existence of negative impacts of tourism. The local residents and the entrepreneurs of Cape Cod, Massachusetts, were interviewed to measure their perception of how tourism impacts the different domains of livelihood. Comparisons were made between the respondents' attitudes towards tourism and their dependence on tourism for a livelihood (Pizam, 1978). Research by Selwyn (1992) was to identify some of the reasons why tourism needs to be taken seriously by those concerned with community development both in the Third World and in Europe. The local political-economic issues and questions of tourism and the sociocultural change of destinations were considered.

Numerous researchers and scholars of tourism in the last two decades have considered the short- and long-term viability of the tourism business in receptive tourist regions. Rebollo and Baidal (2003) use an operative definition of sustainable tourism development that makes possible the effective application of its principles. From this basis, a system of sustainability indicators is developed that can be applied to Torrevieja, a Spanish Mediterranean destination that is notable for the size of its tourism industry and for its supply of holiday homes. The territorial and socioeconomic transformations that have resulted from Torrevieja's tourism development, along with the new local policies in response to these transformations, highlight both the contradictions and the chances of reconciling economic growth with sustainable development. A similar research by Andriotis and Vaughan (2007) focused on the identification and explanation of the attitudes of a sample of urban residents toward tourism development on Crete and their grouping with respect to these attitudes. Education and employment in tourism were found to be the major single factors af- fecting the attitudes of residents of the island of Crete. Andereck et al. (2007) investigated the differences between Hispanic and Anglo residents of the State of Arizona (USA) with respect to their perceptions of tourism and quality of life in terms of their ethnicity, framed with the context of ethnicity marginality theory.

A valuable contribution in terms of spatial planning of tourism activities of a destination was provided by the study in which researchers compare attitudes of locals towards tourism development in the Otways region of Victoria, Australia, using traditional survey research questions and a contemporary method for measuring spatial preferences for development (Raymond \& Brown, 2007). The results from the survey data showed conditional support for tourism growth and development in the Otway Hinterland and along the Otway Coast, irrespective of residence geographical distance from the centre of tourist activities.

Scientific research in the neighbouring regions similar to the Municipality of Vrsar are significant, too. Nemec Rudež and Vodeb (2010) considered the Slovenian coastal destinations of Koper and Piran using a questionnaire. The findings reveal that the residents' perceptions of tourism differ between municipalities which have different tourism concentrations. In fact, residents in the municipality with the higher tourism concentration perceive more negative tourism impacts, whilst, on the other hand, they do not perceive more positive tourism impacts. Vojnović (2013) examined the selected sociocultural characteristics of sustainable tourism in the nearest vicinity of Vrsar: inland Istria. The following sociocultural indicators of sustainable tourism were selected: the density of the registered and protected cultural and historical heritage relative to area size of towns and villages, the proportion of tourists who understand the language of the local population, the overall security measured as the ratio of criminal conducts and offenses of disturbing public order committed by tourists against the total number of such violations, the attitudes of the local population and accommodation owners towards tourism, as well as the attitudes of the municipal representatives. The attitudes of the local population and accommodation owners towards tourism were examined by adminis- 
tering the questionnaire which showed that tourism is an acceptable and desirable activity. In her analysis of the cultural tourism development potential of the city of Pula, Urošević (2012) analysed the perceptions and attitudes of the key stakeholders, including local residents, related to sustainable valorisation of the key local cultural resources, using questionnaires and interviews. The focus of Marković and FuerstBjelišs research (2015) is the identification of an individual with the spatial identity of a region and investigation of the effects on the sustainable development of tourism, based on a case study of the cities of Bjelovar and Čakovec in the Croatian Hinterland. The effects of tourism on the local community's quality of life are significant, which depends on the quality of a destination itself and on its sustainable development.

Šegota et al. (2017) considered the impact of residents' informedness and involvement on perception of tourism impact, taking the case of the destination Bled. The main research instrument was a selfadministered questionnaire. The finding of their study has shown that highly informed and highly involved residents had better perceptions of tourism's positive impacts than all other groups, whereas those residents who are poorly informed and weakly involved had more negative perceptions of tourism impacts than others.

The sustainability aspects which concern the local community, and which could be analysed include: decent livelihood opportunities; the number of tourism businesses owned and operated by the locals; local communities' share of profits from tourism; training of locals to acquire the competencies and skills for participating in heritage tourism; respect for local intellectual property; locals' accessibility to heritage as a tourism resource and use of tourism facilities; and the local community's participation in decision-making in relation to tourism development of heritage resource (involvement in the planning, research and decisionmaking process, community satisfaction with tourism practice and heritage conservation, etc.) (Xiang and Wall, 2005; Terzić at al., 2014).

In the next section, the authors present the results of empirical research related to the attitudes and expectations of the residents of the Municipality of Vrsar regarding the potentials of sustainable valorisation of local cultural heritage.

\section{Analysis of Local Population Attitudes and Expectations}

Research Methodology

Destination dynamics of Istria County, as Croatia's most developed tourist region, and the Municipality of Vrsar, as a typical Mediterranean destination, including a comparative analysis of the European and Croatian best practices regarding archaeological tourism, as well as the analysis of the first phase of the research which involved 15 experts through focus groups and interviews, are elaborated in previous research (Afrić Rakitovac et al., 2018).

The aim of the second phase of the conducted empirical research was to analyse the attitudes of the local population in the Municipality of Vrsar regarding sustainable valorisation of cultural and archaeological heritage.

The research involved the local community and was carried out on a sample of 182 inhabitants, i.e. 8.5\% of the total population in Vrsar (in 2015, there were 2,149 inhabitants). The research instrument was a questionnaire consisting of 15 questions, out of which three were closed questions, while twelve were openended questions. The questionnaire was previously tested on a sample of 30 inhabitants involved in a workshop organised as part of the project in April 2018. The final sample has embraced different groups of inhabitants from the local community (persons employed in the public sector and private companies, and members of civil organisations). The respondents' answers were collected by students as part of their practical education. The students were trained by the authors. The research was conducted in May 2018.

The research hypotheses of the empirical research were: (1): the local population supports tourism development in the Municipality of Vrsar; (2): the local population recognises potentials of cultural tourism development as a sustainable alternative to the current model of mass tourism; (3): the local population is not well informed about the archaeological heritage in the municipality as a potential for sustainable development or cultural tourism. 
Table 1 Sample Structure by Gender, Age, Level of Education, and Actual Position in the Labour Market

\begin{tabular}{|c|c|c|c|}
\hline Category & Item & $f$ & $f(\%)$ \\
\hline \multirow[t]{3}{*}{ Gender } & Male & 109 & 59.9 \\
\hline & Female & 73 & 40.1 \\
\hline & Total & 182 & 100.0 \\
\hline \multirow[t]{6}{*}{ Age } & $18-29$ & 21 & 11.5 \\
\hline & $30-39$ & 53 & 29.1 \\
\hline & $40-49$ & 62 & 34.1 \\
\hline & $50-59$ & 34 & 18.7 \\
\hline & $>60$ & 12 & 6.6 \\
\hline & Total & 182 & 100.0 \\
\hline \multirow[t]{5}{*}{ Level of education } & Elementary school & 3 & 1.6 \\
\hline & Secondary school & 90 & 49.5 \\
\hline & University & 71 & 39.0 \\
\hline & Master study & 18 & 9.9 \\
\hline & Total & 182 & 100.0 \\
\hline \multirow{6}{*}{$\begin{array}{l}\text { Actual position in } \\
\text { the labour market }\end{array}$} & Employed & 127 & 69.8 \\
\hline & Entrepreneur & 31 & 17.0 \\
\hline & Student & 3 & 1.6 \\
\hline & Retiree & 9 & 4.9 \\
\hline & Unemployed & 12 & 6.6 \\
\hline & Total & 182 & 100.0 \\
\hline
\end{tabular}

The paper presents selected questions and answers. The data have been analysed by methods of descriptive analysis and the one-way ANOVA analysis, processed by means of the SPSS programme 24.0.

\section{Sample Characteristics}

The characteristics of the sample are presented in Tables 1 and 2. There were $59.9 \%$ male and $40.1 \%$ female participants. Concerning the age structure, the largest was the age group from $40-49$, followed by those from 30-39, and the age group from 50-59. Regarding the levels of education, the largest group of respondents were those with a secondary school degree, followed by those with a university degree; together they comprise $88.5 \%$ of the sample. Concerning the actual position in the labour market, the majority of respondents (69.8\%) are currently employed, $17 \%$
Table 2 Sample Structure ba the Impact of Tourism Earnings on Household Income

\begin{tabular}{lrr}
\hline Options & $f$ & $f(\%)$ \\
\hline $\begin{array}{l}\text { Larger part of the household income is } \\
\text { realised through tourism-related activities }\end{array}$ & 102 & 56.0 \\
$\begin{array}{l}\text { Smaller part of the household income is } \\
\text { realised through tourism-related activities }\end{array}$ & 52 & 28.6 \\
$\begin{array}{l}\text { Household income is independent of } \\
\text { tourism-related activities }\end{array}$ & 28 & 15.4 \\
\hline Total & 182 & 100.0 \\
\hline
\end{tabular}

are entrepreneurs, $6.6 \%$ are unemployed, $4.9 \%$ are retired and $1.6 \%$ are students. Regarding the impact of tourism earnings on the respondents' household income, the majority of them (56.0\%) report that a large part of their household income is related to tourism activities, for $28.6 \%$ of them such impact is small, while for $15.4 \%$ of respondents their household income is not affected by tourism activities. We can conclude that the majority of the local population is engaged in tourism and dependent on tourism-related activities.

\section{Research Results}

The first part of the questionnaire explored the local population's attitudes towards the proposed statements related to the impacts of tourism on the local community. As indicated in Table 3, the local population was mainly satisfied with tourism development in the municipality (arithmetic mean on Likert's scale higher than 4). The respondents expressed the highest levels of agreement with the following statements: tourists are welcome regardless of their country of origin (4.68), tourism contributes to higher levels of employment in the Municipality of Vrsar (4.59), tourism is the most important economic activity in the municipality (4.47), tourism development benefits the majority of the population in Vrsar (4.47), and tourists' language(s) are not a barrier for communication (4.14). The respondents expressed the lowest levels of agreement regarding the possibilities of active participation of the local population in the tourism planning process (3.32), the contribution of tourism to environmental protection (3.45), and levels of satisfaction with cultural attractiveness in the municipality (3.24). 
Table 3 Local Population's Attitudes Regarding the Proposed Statements

\begin{tabular}{|c|c|c|c|c|c|c|c|c|}
\hline \multirow[t]{2}{*}{ Statements } & \multicolumn{5}{|c|}{ Frequencies } & \multirow[t]{2}{*}{ (1) } & \multirow[t]{2}{*}{ (2) } & \multirow[t]{2}{*}{ (3) } \\
\hline & 1 & 2 & 3 & 4 & 5 & & & \\
\hline Tourism contributes to higher employment in Vrsar & 1 & 4 & 5 & 49 & 123 & 4.59 & 0.706 & -2.177 \\
\hline Tourism is the most important economic activity in Vrsar & 1 & 3 & 11 & 62 & 105 & 4.47 & 0.733 & -1.586 \\
\hline Tourism develop. benefits the majority of the population in Vrsar & 1 & 7 & 8 & 56 & 110 & 4.47 & 0.798 & -1.770 \\
\hline Tourists do not hinder daily life and work in Vrsar & 8 & 23 & 50 & 55 & 46 & 3.59 & 1.127 & -0.434 \\
\hline I actively participate in the tourism planning process in Vrsar & 19 & 29 & 49 & 45 & 40 & $3 \cdot 32$ & 1.269 & -0.275 \\
\hline Tourism contributes to environmental protection in Vrsar & 9 & 22 & 64 & 52 & 35 & 3.45 & 1.085 & -0.291 \\
\hline Tourists' language(s) are not a barrier for communication & 2 & 9 & 20 & 81 & 70 & 4.14 & 0.880 & -1.119 \\
\hline Tourists are welcome regardless of the country of origin & 1 & 2 & 5 & 38 & 136 & 4.68 & 0.637 & -2.586 \\
\hline Tourists contribute to the pres. of customs and cult. heritage & 1 & 11 & 42 & 65 & 63 & 3.98 & 0.934 & -0.573 \\
\hline Estimate the level of satisfaction with the cultural offer in Vrsar & 13 & 36 & 59 & 43 & 31 & 3.24 & 1.163 & -0.089 \\
\hline
\end{tabular}

Notes Column headings are as follows: (1) arithmetic mean, (2) standard deviation, (3) skewness.

Table 4 Statistical Differences Related to the Local Population's Attitudes Regarding the Proposed Statements: Gender and Age (Mean Values)

\begin{tabular}{|c|c|c|c|c|c|c|c|c|c|c|c|}
\hline \multirow[t]{2}{*}{ Statements } & \multicolumn{4}{|c|}{ Gender } & \multicolumn{6}{|c|}{ Age } & \multirow[b]{2}{*}{$p$} \\
\hline & (1) & (2) & $P$ & $p$ & $18-29$ & $30-39$ & $40-49$ & $50-59$ & $>60$ & $P$ & \\
\hline $\begin{array}{l}\text { Tourism contributes to higher } \\
\text { employment in Vrsar }\end{array}$ & 4.62 & 4.53 & 0.704 & 0.403 & $4 \cdot 38$ & 4.53 & 4.56 & 4.79 & 4.75 & 1.463 & 0.216 \\
\hline $\begin{array}{l}\text { Tourism is the most important } \\
\text { economic activity in Vrsar }\end{array}$ & 4.42 & 4.53 & 1.024 & 0.313 & 4.48 & 4.19 & 4.56 & 4.74 & 4.42 & 3.523 & 0.009 \\
\hline $\begin{array}{l}\text { Tourism development benefits the } \\
\text { majority of the population } \\
\text { in Vrsar }\end{array}$ & 4.41 & 4.55 & 1.254 & 0.264 & 4.52 & 4.28 & 4.42 & 4.71 & 4.75 & 1.966 & 0.106 \\
\hline $\begin{array}{l}\text { Tourists do not hinder daily life } \\
\text { and work in Vrsar }\end{array}$ & 3.61 & 3.58 & 0.031 & 0.860 & 3.38 & $3 \cdot 34$ & 3.65 & 3.97 & 3.75 & 1.940 & 0.106 \\
\hline $\begin{array}{l}\text { I actively participate in the tourism } \\
\text { planning process in Vrsar }\end{array}$ & 3.17 & 3.53 & 3.567 & 0.061 & 2.76 & 3.21 & 3.45 & 3.59 & $3 \cdot 33$ & 1.691 & 0.154 \\
\hline $\begin{array}{l}\text { Tourism contributes to environ- } \\
\text { mental protection in Vrsar }\end{array}$ & 3.42 & 3.49 & 0.187 & 0.666 & 3.19 & 3.13 & 3.40 & 3.97 & 4.08 & 4.822 & 0.001 \\
\hline $\begin{array}{l}\text { Tourists' languages are not a bar- } \\
\text { rier for communication }\end{array}$ & 4.15 & 4.14 & 0.005 & 0.942 & 4.00 & 3.89 & 4.23 & 4.47 & 4.17 & 2.672 & 0.034 \\
\hline $\begin{array}{l}\text { Tourists are welcome regardless of } \\
\text { the country of origin }\end{array}$ & 4.68 & 4.68 & 0.004 & 0.950 & 4.81 & 4.53 & 4.60 & 4.88 & 5.00 & 2.969 & 0.021 \\
\hline $\begin{array}{l}\text { Tourists contribute to the preser- } \\
\text { vation of customs and cultural } \\
\text { heritage }\end{array}$ & 4.02 & 3.92 & 0.505 & 0.478 & 3.76 & 3.74 & 4.0 & 4.24 & 4.58 & 3.238 & 0.014 \\
\hline $\begin{array}{l}\text { Estimate the level of satisfaction } \\
\text { with the cultural offer in Vrsar }\end{array}$ & 3.17 & $3 \cdot 34$ & 1.016 & 0.315 & 3.05 & 3.06 & 3.24 & 3.41 & 3.83 & 1.534 & 0.218 \\
\hline
\end{tabular}

Notes Column headings are as follows: (1) female, (2) male. Tested by one-way A NovA. 
Table 5 Statistical Differences Related to the Local Population's Attitudes Regarding the Proposed Statements: Level of Education and Impact on Household Income (Mean Values)

\begin{tabular}{|c|c|c|c|c|c|c|c|c|c|c|c|}
\hline \multirow[t]{2}{*}{ Statements } & \multicolumn{6}{|c|}{ Level of education } & \multicolumn{5}{|c|}{ Impact on household income } \\
\hline & (1) & (2) & (3) & (4) & $P$ & $p$ & Large & Small & No & $P$ & $p$ \\
\hline $\begin{array}{l}\text { Tourism contributes to higher } \\
\text { employment in Vrsar }\end{array}$ & 2.67 & 4.64 & 4.58 & 4.67 & 8.665 & 0.000 & 4.73 & 4.62 & 4.04 & 11.817 & 0.000 \\
\hline $\begin{array}{l}\text { Tourism is the most important } \\
\text { economic activity in Vrsar }\end{array}$ & 2.67 & 4.57 & 4.45 & 4.33 & 7.530 & 0.000 & 4.60 & $4 \cdot 37$ & 4.18 & 4.459 & 0.013 \\
\hline $\begin{array}{l}\text { Tourism development benefits the } \\
\text { majority of the population } \\
\text { in Vrsar }\end{array}$ & 2.67 & 4.49 & 4.55 & 4.33 & 5.988 & 0.001 & 4.59 & 4.40 & 4.14 & 3.760 & 0.025 \\
\hline $\begin{array}{l}\text { Tourists do not hinder daily life } \\
\text { and work in Vrsar }\end{array}$ & 2.67 & 3.61 & 3.76 & 3.00 & 2.961 & 0.034 & 3.75 & 3.48 & 3.25 & 2.525 & 0.083 \\
\hline $\begin{array}{l}\text { I actively participate in the tourism } \\
\text { planning process in Vrsar }\end{array}$ & 3.00 & 3.29 & 3.46 & 2.94 & 0.914 & 0.436 & 3.62 & 2.92 & 2.96 & 6.866 & 0.001 \\
\hline $\begin{array}{l}\text { Tourism contributes to environ- } \\
\text { mental protection in Vrsar }\end{array}$ & 3.33 & 3.46 & 3.58 & 2.94 & 1.660 & 0.177 & 3.52 & 3.54 & 3.04 & 2.463 & 0.088 \\
\hline $\begin{array}{l}\text { Tourists' languages are not a bar- } \\
\text { rier for communication }\end{array}$ & 3.00 & 4.16 & 4.21 & 4.00 & 2.026 & 0.112 & 4.27 & 4.02 & 3.89 & 2.839 & 0.061 \\
\hline $\begin{array}{l}\text { Tourists are welcome regardless of } \\
\text { the country of origin }\end{array}$ & 2.67 & 4.77 & 4.72 & 4.44 & 13.882 & 0.000 & 4.73 & 4.69 & 4.50 & 1.392 & 0.251 \\
\hline $\begin{array}{l}\text { Tourists contribute to the preser- } \\
\text { vation of customs and cultural } \\
\text { heritage }\end{array}$ & 3.33 & 3.16 & 3.35 & 3.17 & 2.292 & 0.080 & 4.04 & 4.00 & 3.71 & 1.355 & 0.261 \\
\hline $\begin{array}{l}\text { Estimate the level of satisfaction } \\
\text { with the cultural offer in Vrsar }\end{array}$ & 2.67 & 3.94 & 4.04 & 4.11 & 0.404 & 0.751 & $3 \cdot 36$ & 3.19 & 2.86 & 2.155 & 0.119 \\
\hline
\end{tabular}

Notes Column headings are as follows: (1) elementary, (2) secondary, (3) university, (4) master. Tested by one-way A Nova.

The results presented in Table 3 were further analysed using the one-way ANOva analysis, as presented in Tables 4 and 5 . As indicated in Table 4, it can be concluded that there were not statistically significant differences in the respondents' answers according to gender, since all levels of significance are higher than $5 \%$ $(p<0.05)$. However, there were statistically significant differences according to the respondents' ages found for five statements: regarding tourism contribution to environmental protection $(p=0.001<0.05)$, regarding tourism as the most important economic activity in the municipality $(p=0.009<0.05)$, regarding the statement that tourists are welcome regardless of the country of origin $(p=0.021<0.05)$ and regarding tourists' language(s) not representing a barrier for communication $(p=0.034<0.05)$. Younger respon- dents are more sceptical regarding the positive impact of tourism on environmental protection and the impact of tourism on preservation of customs and cultural heritage.

As indicated in Table 5, there were statistically significant differences in relation to the respondents' levels of education found for five statements: regarding the contribution of tourism to higher employment rates in the municipality $(p<0.0,05)$, regarding tourism as the most important economic activity in $\operatorname{Vrsar}(p<0,05)$, regarding the statement that tourists are welcome regardless of the country of origin $(p<$ $0.05)$, regarding the statement that tourism development benefits the majority of the population $(p=0.001$ $<0.05$ ), and regarding the statement that tourists do not hinder daily life and work in the municipality. It 
Table 6 The Importance of Proposed Attractions of Vrsar as a Tourism Destination

\begin{tabular}{|c|c|c|c|c|c|c|c|c|}
\hline \multirow[t]{2}{*}{ Statements } & \multicolumn{5}{|c|}{ Frequencies } & \multirow[t]{2}{*}{ (1) } & \multirow[t]{2}{*}{ (2) } & \multirow[t]{2}{*}{ (3) } \\
\hline & 1 & 2 & 3 & 4 & 5 & & & \\
\hline The vicinity of the Adriatic sea & 1 & 1 & 10 & 50 & 120 & 4.58 & 0.675 & -1.865 \\
\hline The weather and the climate & o & 2 & 9 & 58 & 113 & 4.55 & 0.644 & -1.379 \\
\hline The coast and islands & 3 & 1 & 8 & 47 & 123 & 4.57 & 0.753 & -2.407 \\
\hline Natural and rare land cover type & 1 & 5 & 26 & 64 & 86 & 4.26 & 0.844 & -1.023 \\
\hline The Lim Channel & 1 & 3 & 8 & 56 & 114 & 4.53 & 0.710 & -1.848 \\
\hline Parks & 2 & 3 & 23 & 68 & 86 & 4.28 & 0.830 & -1.210 \\
\hline The Kontija Forest & 2 & 4 & 27 & 62 & 87 & 4.25 & 0.868 & -1.130 \\
\hline St. Michael's church & 2 & 10 & 50 & 60 & 60 & 3.91 & 0.959 & -0.506 \\
\hline Monte Ricco archaeological site & 5 & 9 & 43 & 68 & 57 & 3.90 & 0.995 & -0.777 \\
\hline Vrsar's mosaics & 5 & 15 & 44 & 51 & 67 & 3.88 & 1.086 & -0.674 \\
\hline St. Mary's of the Sea church & 1 & 5 & 34 & 70 & 72 & 4.14 & 0.853 & -0.754 \\
\hline Vrsar's old city centre & 2 & 3 & 22 & 55 & 100 & $4 \cdot 36$ & 0.841 & -1.389 \\
\hline Dušan Džamonja’s Park of Sculptures & 1 & 5 & 29 & 68 & 79 & 4.20 & 0.846 & -.0900 \\
\hline The culinary tradition & 4 & 7 & 35 & 69 & 67 & 4.03 & 0.957 & -0.946 \\
\hline Cultural, sports and entertainment manifestations & 6 & 9 & 30 & 63 & 74 & 4.04 & 1.034 & -1.088 \\
\hline
\end{tabular}

Notes Column headings are as follows: (1) arithmetic mean, (2) standard deviation, (3) skewness.

can be observed that the respondents with a higher level of education valuated tourism as an important economic and social phenomenon more frequently than those with a lower level of education.

As indicated in the same table, there were statistically significant differences regarding the impact of tourism on household income for four statements: regarding tourism contribution to higher employment rates in the Vrsar municipality $(p<0.0,05)$, regarding tourism as the most important economic activity in $\operatorname{Vrsar}(p<0,05)$, regarding the statement that tourism development benefits the majority of the population in $\operatorname{Vrsar}(p=0.001<0.05)$ and regarding active participation in the tourism planning process in Vrsar. It can be observed that tourism is considered as more important for respondents who have a larger impact of tourism on their household income. Consequently, those respondents are more interested in active participation in the tourism planning process.

Table 6 indicates the local population's perceptions of the proposed attractions of Vrsar as a tourism destination. As expected, considering the arithmetic mean scores on Likert's scale higher than 4, the local population has recognised the following as the most significant attributes: the Adriatic coast and nearby islands, the pleasant weather and climate, the Lim Channel, Vrsar's old city centre, etc. The local population considers the following as less attractive: Vrsar's mosaics, St. Michael's Church and the Monte Ricco archaeological site.

The following question was related to the perception of the local population about the most common tourist activities of tourists when visiting Vrsar (Table 7). As expected, considering the arithmetic mean scores on Likert's scale higher than 4 , the local population has recognised swimming and other seaside activities, visiting restaurants, walking trails and cycling as the most attractive activities for tourists. Less recognised were participation in the local community's activities, acquiring new experiences, visiting cultural and historical monuments, visiting cultural manifestations, visiting protected nature areas, and participation in sports and entertainment manifestations.

We can conclude that, according to the local popu- 
Table 7 Local Population's Perception of the Most Frequent Activities of Tourists Visiting Vrsar

\begin{tabular}{lrrrrrrrr}
\hline Statements & \multicolumn{3}{c}{ Frequencies } & & $(1)$ & $(2)$ & $(3)$ \\
\cline { 2 - 5 } & & 1 & 2 & 3 & 4 & 5 & & \\
\hline Swimming and other seaside activities & 1 & 2 & 21 & 61 & 97 & 4.38 & 0.775 & -1.206 \\
Visiting protected nature areas & 0 & 9 & 55 & 77 & 41 & 3.82 & 0.836 & -0.176 \\
Cycling & 1 & 2 & 33 & 90 & 56 & 4.09 & 0.760 & -0.607 \\
Visiting restaurants & 0 & 2 & 27 & 80 & 73 & 4.23 & 0.723 & -0.562 \\
Visiting cultural and historical monuments & 4 & 12 & 59 & 79 & 28 & 3.63 & 0.899 & -0.494 \\
Visiting cultural manifestations & & 10 & 58 & 73 & 41 & 3.80 & 0.852 & -0.138 \\
Participation in sports and entertainment manifestations & 2 & 5 & 48 & 78 & 49 & 3.92 & 0.860 & -0.526 \\
Participation in the local community's activities & 8 & 24 & 79 & 49 & 22 & 3.29 & 0.990 & -0.130 \\
Walking trails & 1 & 3 & 37 & 83 & 58 & 4.07 & 0.798 & -0.581 \\
New experiences & 6 & 17 & 69 & 56 & 34 & 3.52 & 1.007 & -0.274 \\
\hline
\end{tabular}

Notes Column headings are as follows: (1) arithmetic mean, (2) standard deviation, (3) skewness.

lation attitudes, tourists still perceive Vrsar as the sunand-sea destination for relaxing active holidays, complemented with enjoying the local food and recreation (swimming, cycling, walking) in beautiful nature.

The second part of the questionnaire consisted of ten open-ended questions aimed to determine the respondents' attitudes regarding the unique features and development potentials of Vrsar as a cultural tourism destination, as well as its greatest advantages and disadvantages. The respondents were asked about the most attractive cultural attractions and manifestations and about their habits when it comes to visiting cultural attractions and manifestations. They were also asked to propose ways for improving presentation of cultural and archaeological attractions, as well as the cultural tourism offer in general. In conclusion, they were asked about the results of the previous cultural tourism projects and expected results of the project ArchaeoCulTour. The results are presented in the swot matrix (Table 8).

When asked about the most recognisable and unique characteristics/attractions of Vrsar, the respondents emphasized the beauty of nature/archipelago/ sea ( $24.7 \%$ of respondents), and the unique cultural heritage symbolised by the romantic/picturesque old city core $(10.9 \%)$, as well as the importance of the first and biggest naturist camp in Europe - Koversada (10.9\%). The participants also mentioned the
Montraker quarry/sculpture school (5.5\%), the famous lover, Giacomo Casanova, who visited Vrsar twice (5.5\%), and the Lim Fjord (5.5\%) as important local brands.

The most frequent answers, regarding the five most attractive cultural and archaeological sites in the area of Vrsar, were: churches - St. Mary's (35.7\%), Dušan Džamonja's Park (27.4\%), the old castle with the city core (24.7\%), the Montraker quarry (16,5\%), Monte Ricco (10.9\%), the mosaics (8.2\%), etc.

The most frequent answers, regarding the five most attractive cultural and tourist manifestations in Vrsar, were: the fishermen fest (33.5\%) Casanovafest (26.4\%), the Old Fair (stari samanj) (19.8\%), concerts (16.5\%), the guitar festival (11.5\%), and the Montraker sculpture school (8.2\%).

When asked how Vrsar could present its cultural and archaeological attractions in a better way, the respondents offered the following answers: through mass media promotion/advertising/online marketing (16.5\%), manifestations (9.9\%), innovative interpretation models/guided tours (8.2\%), investment in infrastructure, founding a new cultural institution, and educating citizens $(2.7 \%)$, presentation through storytelling and themed products/routes (5.5\%), interactive interpretation centres $(2.7 \%)$, cooperation/inclusion of the local community $(8.2 \%)$, destination branding (2.7\%), etc. 
Table 8 swот Matrix on the Sustainable Development Potential of Cultural Heritage in the Municipality of Vrsar: Local Community Perspective

\section{Strengths}

- Favourable geographical position

- Proximity to emitive markets

- Favourable micro-climate

- Small, safe and quiet place

- Beautiful and preserved nature and environment

- Clean sea and nice beaches

- Best auto camps

- Proximity of the lime channel (protected natural area) and islands

- Preserved and rich cultural heritage (old city centre, churches, mosaics, sculpture garden, traditional gastronomy, archaeological sites, etc.)

- Active tourism (bikes, trail and trekking, climbing, kayaking, diving)

- Proximity of Marina Vrsar, one of the best nautical ports in croatia

Opportunities

- Connecting/networking the existing attractions into new routes and cultural itineraries

- Adequate presentation and interpretation of the rich cultural heritage

- Adequate presentation and interpretation of the rich cultural heritage

- Investment in the key cultural and natural resources (the old city core, Kontija, infrastructure), new festivals and manifestations

- Gastronomy

- Some specific cultural resources such as the mosaics

- Monterico, the Montraker quarry

- Džamonja's park and museum

- Churches

- New museums and interpretation centres, creative workshops, open-air theatre (Montraker),

- Diving at archaeological sites
Weakness

- Sun and sea tourism model

- Insufficient involvement of the local community in tourism planning and realisation of projects

- Insufficient valorisation of cultural heritage

- Cultural heritage is not recognised as a motive for choosing Vrsar as a tourism destination

- Lack of an institution for cultural and natural heritage management

- Insufficient sport facilities

- Insufficient entertainment facilities

Threats

- Competition of neighbouring tourism destinations with similar tourism concept based on sun and sea

- Decreased interest from tourists for the sea and sun tourism development model

- Climate changes
Regarding their usual visiting of cultural manifestations in Vrsar, 50\% of participants answered negatively, while another 50\% said they visit the following manifestations: the fishermen fest (15.9\%), the Old Fair (stari samanj) (12.6\%), Casanovafest (12.6\%), concerts (12.1\%), the guitar festival (4.9\%), the sculpture school (3.3\%), etc.

When asked if they have suggestions for improving the cultural tourism offer in Vrsar, the respondents mentioned the following: providing better information and promotion, reducing fishermen fests and creating events related to the most specific elements of the local identity, open-air museums, investing in the most important cultural resources (the old city core), improving signalisation and interpretation, as well as the quality of the cultural tourism offer, creating new cultural itineraries, educating tourist guides about local attractions, networking with similar European destinations, involving the local community in heritage valorisation and interpretation, applying for the $\mathrm{EU}$ projects and funds, etc.

Regarding their awareness about past cultural tourism projects in Vrsar, most of our respondents answered negatively, while only $20.9 \%$ of them mentioned some recent projects related to the new cycling routes, workshops and manifestations. As positive effects of such projects, they mentioned investments and better valorisation of cultural resources, a better image of Vrsar as a cultural tourism destination, raising awareness of local citizens about their heritage, the 
preservation of monuments and old traditions, extended tourist season, new segments of tourists, etc.

Concerning their awareness about the ArchaeoCulTour project, only $22.5 \%$ of respondents answered positively, while most of them were uninformed. What they expect from the project is better networking and coordination of key stakeholders, better media coverage, more satisfied tourists, better quality of cultural tourism offer, the preservation of cultural, natural and archaeological heritage, better presentation and innovative interpretation, extended tourist season, etc.

When asked if they had further suggestions, there were only 17 (9.3\%) positive answers, mostly related to innovations in the cultural tourism offer (new and more inclusive manifestations; new cultural infrastructure, suggestions related to the local infrastructure, signalisation and the role of the municipality in the project, giving a chance to young people and experts, etc).

\section{Discussion}

The research has shown that the local population in Vrsar is partially satisfied with the development of tourism in the municipality. The respondents have recognised the importance of tourism for the development of the local economy and increasing the living standards of the majority of the population. The research has shown that younger respondents are more sceptical regarding the positive impact of tourism on environmental protection and the impact of tourism on preservation of customs and cultural heritage. The respondents with a higher level of education valuated tourism as an important economic and social phenomenon more frequently than those with a lower level of education. In addition, tourism is considered as more important for respondents who have a larger impact of tourism on their household income. Although most of the local population is professionally engaged in tourism, they are not satisfied with the level of inclusion of residents in tourism planning and in heritage management.

According to local population attitudes, tourists still perceive Vrsar as the sun-and-sea destination for relaxing active holidays, complemented with enjoying the local food and recreation (swimming, cycling, walking) in beautiful nature. Although aware of the unique characteristics of the local natural and cultural heritage, as well as the good geographical position and proximity to emissive markets as the most valuable attractiveness factors, the respondents emphasized the neglect of the infrastructure, lack of quality cultural manifestations (which also explains the fact that only half of respondents visit the manifestations organised mostly during the summer season) and the need for better presented and interpreted cultural attractions as the main problems in the planning of sustainable cultural tourism. The research has shown that local residents are well informed about the main cultural resources and the possibilities of their sustainable valorisation through innovative interpretation models, such as cultural routes, living history, workshops which would include the local community, and interpretation centres. However, only a fifth of them were familiar with past cultural tourism projects implemented in the community, which indicates the need for better visibility and more active participation of the community in existing and future projects.

The results of the community survey are in line with the results of interviews and focus groups with experts organised in the first phase of the research. The authors expect the results of the tourist survey in the next stage would confirm some of the most important issues related to heritage management and sustainable cultural tourism development, as well as the need of capacity building and awareness raising about the local cultural heritage in the process of knowledge (co)creation.

\section{Conclusion}

The conducted research confirmed the main hypotheses: (1) the local population supports tourism development in the Municipality of Vrsar; (2) the local population recognises potentials of cultural tourism development as a sustainable alternative to the current model of mass tourism; (3) the local population is not well informed about the archaeological heritage in the Municipality as a potential for sustainable cultural tourism development.

Although the majority of the local residents (56\% of the sample) are directly employed in tourism, which 
would imply they mostly support tourism development, it is obvious that the community is saturated with the still prevailing model of mass sun-and-sea summer tourism, and that they are looking for a more sustainable model which would involve the locals in the tourism development and heritage management processes. The local residents are also very interested in presenting their local culture, traditions and heritage to their visitors, and they are actively engaged in proposing certain innovative models of sustainable preservation, valorisation and interpretation of the most recognizable cultural resources, such as heritage interpretation training.

Unlike the most recognisable cultural resources in the Municipality of Vrsar, the local community is still not aware of and adequately informed about the value of the local archaeological heritage and its potential for tourism valorisation, which indicates the need for innovative campaigns of awareness raising and capacity building. On the other hand, when asked, they suggested organising educative interactive workshops for the local community, networking and connecting heritage sites through cultural routes and educational paths, and interpretation centres for visitors. They also emphasized the lack of cultural manifestations and entertainment facilities, both for the locals and their visitors, as well as the need for investments in the cultural infrastructure.

The conducted research indicated that the local stakeholders are very interested in the sustainable development of cultural tourism as a sustainable alternative to the current model of mass tourism, and that they want to be involved in the tourism planning process, better informed and included in the participatory heritage management models. They agree that the main sustainability issues in the Municipality of Vrsar: high seasonality, mass tourism and infrastructure problems, could be resolved through sustainable valorisation of local cultural and natural resources by creating innovative tourism experiences, and they are interested in participating in this co-creating process.

The authors are aware of some limitations of the chosen methodology, which could not include or measure all dimensions of sustainability of cultural and tourism development. The comparative perspective would also be useful. Therefore, the authors expect that the results of the third and last phase of the research - the tourist survey, would allow a better insight into destination dynamics and more concrete proposals for innovations in the cultural tourism offer, and an adequate presentation and interpretation of the neglected archaeological heritage.

Since Vrsar represents the model of a typical coastal tourist destination in the Mediterranean, characterised by mass tourism and a remarkable seasonality, as well as huge potential for sustainable cultural tourism development through community involvement, the authors believe the final results and recommendations will be useful and applicable in the broader Euro-Mediterranean context. Research results confirm the need for capacity building and awareness raising among the key stakeholders about the local cultural heritage in the process of knowledge (co)creation and distribution in documented dynamic destination changes.

\section{Acknowledgments}

This work has been supported in part by the Croatian Science Foundation under the project PAR-2017-02-1.

\section{References}

Afrić Rakitovac, K., \& Urošević, N. (Eds.). (2017). Models of valorisation of cultural heritage in sustainable tourism. Juraj Dobrila University of Pula.

Afrić Rakitovac, K., Urošević, N., \& Vojnović, N. (2018). Project ArchaeoCulTour: Innovative valorization of archaeological heritage in Istria County through sustainable cultural and creative tourism. In V. Katsoni \& M. Segarra-Oña (Eds.), Smart tourism as a driver for culture and sustainability (pp. 61-77). Springer.

Andereck, K., \& Nyaupane, G. (2011). Exploring the nature of tourism and quality of life perceptions among residents. Journal of Travel Research, 50(3), 248-26o.

Andereck, K., \& Vogt, C. (200o). The relationship between residents' attitudes toward tourism and tourism development options. Journal of Travel Research, 39(August), 27-36.

Andereck, K., Valentine, K., Knopf, R., \& Vogt, C. (2005). Residents' perceptions of community tourism impacts. Annals of Tourism Research, 32(4), 1056-1076.

Andereck, K., Valentine, K., Vogt, C., \& Knopf, R. (2007). A cross-cultural analysis of tourism and quality of life 
perceptions. Journal of Sustainable Tourism, 15(5), 483502.

Andriotis, K., \& Vaughan, R. (2003). Urban residents' attitudes toward tourism development: The case of Crete. Journal of Travel Research, 42(2), 172-185.

Ap, J. (1992). Residents' perceptions of tourism impacts. Annals of Tourism Research, 19(4), 665-690.

Byrd, E. T., Bosley, H. E., \& Dronberger, M. G. (2009). Comparison of stakeholder perceptions of tourism in rural eastern North Carolina. Tourism Management, 30(5), 693-703.

Choi, H. C., \& Murray, I. (2010). Resident attitudes toward sustainable community tourism. Journal of Sustainable Tourism 18(4), 575-594.

Currie, R. R., Seaton, S., \& Wesley, F. (2009). Determining stakeholders for feasibility analysis. Annals of Tourism Research, 36(1), 41-63.

Čorak, S. (Ed.). (2011). Izazovi upravljanja turizmom. Institute for Tourism.

Dyer, P., Gursoy, D., Sharma, B., \& Carter, J. (2007). Structural modelling of resident perceptions of tourism and associated development on the Sunshine Coast, Australia. Tourism Management, 28(2), 409-422.

Goodwin, H. (2011). Taking responsibility for tourism. Goodfellow Publishers.

Gunn, C. A. (1994). Tourism planning: Basics, concepts, cases (3rd ed.). Taylor \& Francis.

Gursoy, D., Jurowski, C., \& Uysal, M. (2002). Resident attitudes: A structural modelling approach. Annals of Tourism Research, 29(1), 79-105.

Hall, C. M. (2007). Tourism planning: Policies, processes and relationships. Pearson Prentice Hall.

Hall, C. M., \& Page, S. (2006). The geography of tourism and recreation: Space, place and environment. Routledge.

Hollinshead, K. (1999). Surveillance of the worlds of tourism: Foucault and the eye-of-power. Tourism Management, 2o(1), 7-23.

Ioannides, D. (1995). A flawed implementation of sustainable tourism: The experience of Akamas, Cyprus. Tourism Management, 16(8), 583-592.

Klarin, T. (2018). Assumptions for a successful implementation of the concept of sustainable tourism development: Example of urban destinations of the Republic of Croatia. Acta Turistica, 30(1), 43-85.

Lankford, S. V. (1994). Attitudes and perceptions toward tourism and rural regional development. Journal of Travel Research, 32(2), 35-43.

Marković, I., \& Fuerst-Bjeliš, B. (2015). Spatial identity as a driving force in tourism development: Comparative analysis of the Bjelovar and Čakovec regions. Hrvatski geografski glasnik, 77(1), 71-80.

McGehee, N. G., \& Andereck, K. L. (2004). Factors predicting rural residents' support of tourism. Journal of Travel Research, 43(2), 131-140.

Mihalic, T. (2014). Sustainable-responsible tourism discourse: Towards 'response-sustainable' tourism. Journal of Cleaner Production, 111(Part B), 461-470.

Murphy, P. E. (1985). Tourism: A community approach. Methuen.

Nemec Rudež, H., \& Vodeb, K. (2010). Perceived tourism impacts in municipalities with different tourism concentration. Turizam, 58(2), 161-172.

Nunkoo, R., \& Ramkissoon, H. (2010). Small island urban tourism: A residents' perspective. Current Issues in Tourism, 13(1), 37-6o.

Ong, C. E., Ryan, C., \& McIntosh, A. (2014). Power-knowledge and tour-guide training: Capitalistic domination, utopian visions and the creation of UNESCo's HomoTurismos in Macao. Annals of Tourism Research, 48, 221234.

Perdue, R. R., Long, P. T., \& Allen, L. (1990). Resident support for tourism development. Annals of Tourism Research, 17(4), 586-599.

Picard, R. (2017). Heritage for all: The Council of Europe approach. Cartaditalia 1(2018 European Year of Cultural Heritage), 71-9o.

Pizam, A. (1978). Tourism's impacts: The social costs to the destination community as perceived by its residents. Journal of Travel Research, 16(8), 8-12.

Raymond, C., \& Brown, G. (2007). A spatial method for assessing resident and visitor attitudes towards tourism growth and development. Journal of Sustainable Tourism, 15(5), 520-540.

Rebollo, J. F. V., \& Baidal, J. A. I. (2003). Measuring sustainability in a mass tourist destination: Pressures, perceptions and policy responses in Torrevieja, Spain. Journal of Sustainable Tourism, 11(2-3), 181-203.

Richards, G. (Ed.) (2007). Cultural tourism: Global and local perspectives. The Haworth Hospitality Press.

Richards, G., \& Hall, D. (Eds.). (2003). Tourism and sustainable community development. Routledge.

Richards, G., \& Munster, W. (Eds.). (2010). Cultural tourism research methods. СА B $\mathrm{I}$.

Robson, J., \& Robson, I. (1996). From shareholders to stakeholders: Critical issues for tourism marketers. Tourism Management, 17(7), 533-540.

Selwyn, T. (1992). Tourism society and development. Community Development Journal, 27(4), 353-36o. 
Šegota, T., Mihalič, T., \& Kǔšcer, K. (2017). The impact of residents' informedness and involvement on perceptions of tourism impacts: The case of the destination Bled. Journal of Destination Marketing and Management, 6(3), 196206.

Terzić, A., Jovičić, A., \& Simeunović-Bajić, N. (2014). Community role in heritage management and sustainable tourism development: Case study of the Danube Region in Serbia. Transylvanian Review of Administrative Sciences (Special Issue), 183-201.

Tosun, C. (2000). Limits to community participation in the tourism development process in developing countries. Tourism Management, 21(6), 613-633.

Tosun, C. (2005). Stages in the emergence of a participatory tourism development approach in the developing world. Geoforum, 36(3), 333-352.

Urošević, N. (2012). Cultural identity and cultural tourism: Between the local and the global (A case study of Pula, Croatia). Singidunum Journal, 9(1), 67-76.

Vojnović, N. (2013). Socio-cultural characteristics of sustainable tourism in inland Istria. Socijalna ekologija, 22(2), 85-106.
Wall, G., \& Mathieson, A. (2005). Tourism: Change, impacts, opportunities. Pearson Education.

Wang, Y. A., \& Pfister, R. E. (2008). Residents' attitudes toward tourism and perceived personal benefits in a rural community. Journal of Travel Research, 47(1), 84-93.

Winter, T. (2015). Heritage diplomacy. International Journal of Heritage Studies, 21(10), 997-1015.

World Tourism Organization. (2016). A road map for celebrating together [Brochure].

Xiang, Y., \& Wall, G. (2005, August). Heritage conservation and local communities: Pressing issues in the developing countries [Paper presentation]. 3rd Sino-Korea International Tourism Conference, Weihai, China.

Zolfani, S., Sedaghat, M., Maknoon, R., \& Zavadskas, E. (2015). Sustainable tourism: A comprehensive literature review on frameworks and applications. Economic Research-Ekonomska istraživanja, 28(1), 1-30. 